\title{
Seabirds as indicators of marine resources: black-browed albatrosses feeding on ommastrephid squids in Kerguelen waters
}

\author{
Yves Cherel, Henri Weimerskirch
}

Centre d'Etudes Biologiques de Chizé, Centre National de la Recherche Scientifique, F-79360 Villiers-en-Bois, France

\begin{abstract}
The species, distributions and abundances of squids in the Southern Ocean are difficult to assess by conventional oceanographic means. The study of the food and feeding ecology of squid-eating predators such as procellariiform seabirds appears to be a supplemental way to collect useful information on cephalopod biology. Regurgitations were collected from 52 chicks of the black-browed albatross Diomedea melanophrys at Kerguelen Island in February 1994. Cephalopod remains were removed and identified by means of beaks, gladius and mantle. Squid beaks of the family Ommastrephidae amounted to $55 \%(n=348)$ of the accumulated squid beaks. They were also those most often regurgitated in association with partially digested crowns and mantles ( $90 \%$ of the squid fresh remains, $n=28)$. Two species of ommastrephids equally dominated the squid diet, Martialia hyadesi (only found once in Kerguelen waters) and a Todarodes species, probably $T$, angolensis, previously unknown in the area. The concomitant satellite tracking of 16 adult birds over a total of 35 foraging trips identified their main feeding areas as the inner shelf break to the NE and over a bank to the $\mathrm{SE}$ of Kerguelen Island. Taken together, albatross dietary and foraging data indicate that juveniles of $M$. hyadesi and Todarodes sp. concentrate over the upper shelf slope to the east of Kerguelen Island, some of them occurring in the top $5 \mathrm{~m}$ of the water column where they are caught by the albatrosses.
\end{abstract}

KEY WORDS: Bioindicator - Diet - Antarctic - Marine food web $\cdot$ Satellite tracking

Pelagic squid and fish are highly mobile, patchily distributed and consequently very difficult to survey by conventional oceanographic methods. In the Southern Ocean, squids constitute a key group in the pelagic food webs, but little information is available on species composition, distribution and biology because of the inadequacies of sampling techniques (Clarke 1983, Kock 1987). Dietary data from top predators have been used to overcome this problem and have provided valuable data on squid ecology (Clarke 1980, Imber \& Berruti 1981). For example, the onychoteuthid squid Kondakovia longimana, a major prey item for many sea mammals and birds, was first described in 1972 but has rarely been found in nets (Lu \& Williams 1994), and comparison of squids eaten by a variety of top-predators with those obtained with several kinds of nets shows striking differences in the species, abundance and size of specimens caught (Clarke 1977. Clarke 1983, Rodhouse 1990).

Seabirds are particularly useful samplers of pelagic prey that avoid ships and fishing gear and that often occur in the upper 5 to $10 \mathrm{~m}$ of the water column, i.e. in the layer of the seawater rarely included in acoustic surveys. They can also be useful as sampling agents for otherwise unstudied marine fauna at sites that are not easily or not usually surveyed by conventional means (Montevecchi 1993). Moreover, compared with vessel surveys, data on seabird food and feeding ecology have the advantage of being easily collected and inexpensive and allow a broader spatial and temporal coverage. Until now, attempts to locate bird feeding areas, and thus prey aggregations, with some precision relied mainly upon visual observations and were therefore subordinated to oceanographic cruises. On the other hand, information on diet without knowing the location of feeding areas is of limited use in terms of assessing predator-prey interactions.

The recent development of satellite tracking of large seabirds (Jouventin \& Weimerskirch 1990) along with keys for the identification of hard parts of digested prey (e.g. squid beaks, otoliths) (Clarke 1986, Hecht \& Hecht 1987. Williams \& McEldowney 1990) now allows the use of predators as samplers and indicators of species composition and location of marine cephalopod and fish fauna. Satellite fixes permit the journeys of foraging seabirds to be accurately mapped (Weimerskirch et al. 1993); and, even if foraging tracks do not necessarily equate to precise feeding locations, they allow the areas of potential feeding to be located. Moreover, some albatrosses fly directly to and from a specific marine 
sector where they spend most of their foraging time, thus clearly delimiting zones that are likely to be feeding areas (Weimerskirch \& Robertson 1994).

Here, we report the occurrence and location of aggregations of ommastrephid squids in Kerguelen waters using dietary data and satellite tracking of the black-browed albatross Diomedea melanophrys during the chick-rearing period.

Materials and methods. Food samples were collected from 38 black-browed albatross chicks after a returning parent had completed feeding them at Canyon des Sourcils Noirs $\left(49^{\circ} 41^{\prime}\right.$ S, $70^{\circ} 14^{\prime}$ E, southern Kerguelen Island) between 10 and 27 February 1994. An additional 14 incomplete stomach contents were also taken opportunistically during this period. All samples were kept frozen until analysis in the laboratory. Cephalopod flesh and beaks were subsequently removed from the samples and stored in $70 \%$ ethyl alcohol. Squid beaks were identified by comparison with material held in our own reference collection and by the use of Clarke (1986). Since 2 distinct species of Todarodes with similar beaks occur in Kerguelen waters, Todarodes sp. in the text refers to both $T$. angolensis and $T$ filippovae (see 'Discussion'). The term Ommastrephidae sp. was applied when eroded ommastrephid beaks did not allow differentiation among the 3 species ( $T$. angolensis, $T$ filippovae, Martialia hyadesi) or when only ommastrephid mantle and/or gladius were found in stomach contents. Lower rostral length (LRL) was measured to the nearest $0.1 \mathrm{~mm}$ using Vernier calipers. Allometric equations given by Clarke (1986) and Rodhouse \& Yeatman (1990) were used to estimate dorsal mantle length (ML) and whole wet body mass

Nine satellite transmitters [seven T2038 Toyocom (Toyo Communication Equipment Ltd, Minato-ku, Tokyo, Japan) and two 100 Microwave (Microwave Telemetry Inc., Columbia, MD, USA) platform transmitter terminals] were used successively on a total of 16 individual breeding black-browed albatrosses, thus allowing the recording of 1290 locational fixes during 35 foraging trips in February 1994. Birds visiting their chicks for feeding were captured and fitted with the transmitters, which were attached directly to the back feathers using adhesive tape. The transmitters were then left on the birds during 1 to 4 successive foraging trips before being recovered at the next feeding visit. Satellite fixes were obtained through the Argos system and the data were analysed following Weimerskirch et al. (1993).

Results. In February 1994, the mean ( \pm SD) duration of foraging trips of black-browed albatrosses fitted with transmitters was $4.2 \pm 3.8 \mathrm{~d}$ (range: 0.7 to $21.0 \mathrm{~d}$, $n=35$ ). Satellite locations indicate that during these trips albatrosses foraged mainly over the inner shelf break of Kerguelen Island, only $18 \%$ of the locational fixes being situated over deeper water ( $>1000 \mathrm{~m})$, i.e. the outer shelf break and oceanic area (Fig 1A). The map clearly indicates that birds foraged in northern, eastern and southern waters but never on the western Kerguelen shelf, i.e. rarely $\mathrm{W}$ of $68^{\circ} 30^{\prime} \mathrm{E}$. Four areas showed large numbers of locational fixes. One area along the coast indicated the proximity of the breeding colony. Two other areas were situated on the inner shelf break, the largest and more important zone being $\mathrm{N}$-NE at a distance of 150 to $200 \mathrm{~km}$ from the colony. The smallest was in the South, at a distance of $125 \mathrm{~km}$. The fourth zone was a bank, cited as New Bank in Ensor \& Shaughnessy (1990) or as Shell Bank on the bathymetric chart (Heard Island, Australian Antarctic Division, 1995), situated $480 \mathrm{~km}$ away from the colony at about $51^{\circ} 40^{\prime} \mathrm{S}, 76^{\circ} 30^{\prime} \mathrm{E}$ (Fig. 1A).

From a total of 6,3 food samples regurgitated by chicks recently fed by an adult fitted with a satellite transmitter contained fresh remains of ommastrephid squids. The feeding trips of these 3 adult albatrosses are depicted in Fig. 1B-D. Two of them foraged in the N-NE area, where they caught 1 individual of Todarodes sp. and 1 unidentified ommastrephid, respectively (Fig. 1C, D). The third albatross preyed upon $3 \mathrm{Mar}$ tialia hyadesi over the distant New Bank (Fig. 1B). On their way back from the foraging grounds, albatrosses flew quickly to the colony. For example, the first 2 birds spent 6 and $8.5 \mathrm{~h}$, respectively, on their return trips from the N-NE area (Fig. 1C, D), and the third bird flew for $22 \mathrm{~h}$ to return from New Bank to its breeding colony (Fig. 1B). Interestingly, the squids caught by the latter bird were more fully digested than those taken by the 2 other albatrosses coming from a less distant fishing area.

Analysis of both accumulated beaks and fresh remains in the 38 complete regurgitations of blackbrowed albatross chicks gave a total of 229 individuals of ommastrephid squids, these squids occurring in $87 \%$ of the samples (Table 1 ). When considering all

Tahle 1 Ommastrephid squids in 38 complete stomach contents of black-browed albatross Diomedea melanophrys chicks from Canyon des Sourcils Norrs, Kerguelen Island

\begin{tabular}{|lrcc|}
\hline & $\begin{array}{c}\text { No. of } \\
\text { items }\end{array}$ & $\begin{array}{c}\text { No. of } \\
\text { stomachs }\end{array}$ & $\begin{array}{c}\text { \% Frequency } \\
\text { of occurrence }\end{array}$ \\
\hline Ommastrephidae & 229 & 33 & 86.8 \\
Martialia hyadesi & 45 & 17 & 44.7 \\
Todarodes sp. & 40 & 16 & 42.1 \\
Medium & 37 & 14 & 36.8 \\
Large & 3 & 3 & 7.9 \\
Ommastrephidae sp. & 144 & 23 & 60.5 \\
\hline
\end{tabular}



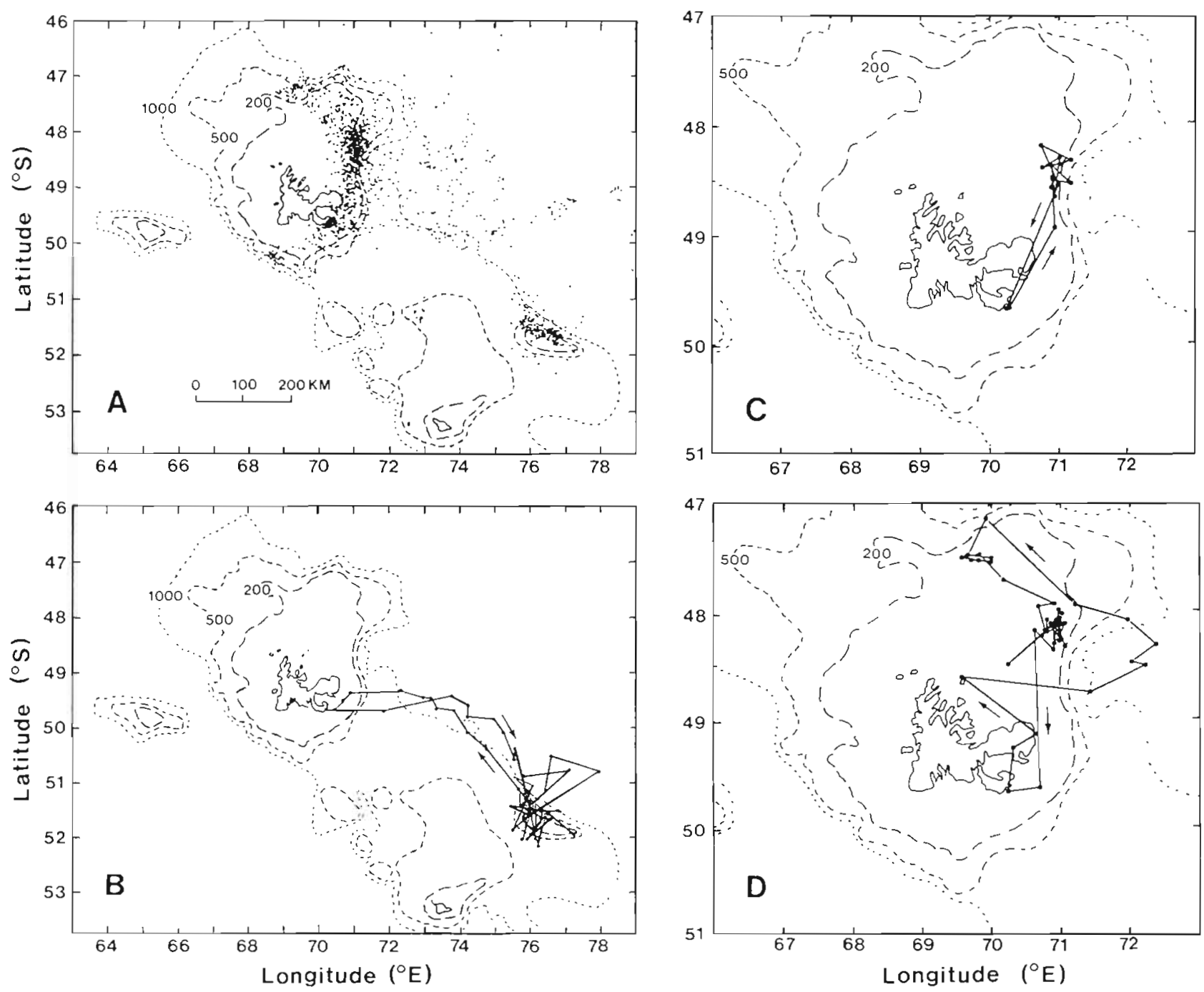

Fig. 1 (A) Distribution of 1290 satellite locational fixes of black-browed albatrosses Diomedea melanophrys from Kerguelen Island during the chick-rearing period, and $(B, C, D)$ detalled tracks of individual foraging trips performed by 3 different birds. Bird B caught 3 individuals of Martialia hyadesi. Bird C 1 Ommastrephidae sp., and Bird D 1 Todarodes sp. Each data point corresponds to 1 satellite fix, and straight lines were drawn between consecutive fixes to delineate tracks of foraging trips. Arrows indicate fhight direction

52 samples, upper and lower beaks of ommastrephids amounted to $55 \%(n=348)$ of the accumulated squid beaks. Beaks of ormmastrephids were also those most often regurgitated in association with partially digested buccal crowns and mantles $190 \%$ of the squid fresh remains, $n=28$ )

The squid diet was equally dominated in terms of numbers and percent frequency by Martialia hyadesi and Todarodes sp. (Table 1). The size-frequency distribution of the LRL for $M$. hyadesi shows a single peak (Fig. 2), the mean value $( \pm \mathrm{SD}$ ) being $4.5 \pm 0.3 \mathrm{~mm}$ (range: 3.9 to $5.2 \mathrm{~mm}$ ). The $\mathrm{ML}$ of $M$. hyadesi estimated from LRL was $235 \pm 8 \mathrm{~mm}$ (218 to $254 \mathrm{~mm}$ ) and the mean body mass $231 \pm 28 \mathrm{~g}$ (175 to $301 \mathrm{~g}$ ). Two size classes of Todarodes sp. beaks were found (Fig. 2). The main peak occurred for a LRL of $5.1 \pm 0.4 \mathrm{~mm}$ (4.4 to $5.7 \mathrm{~mm}$ ), which corresponds to an estimated ML and body mass of $198 \pm 15 \mathrm{~mm}$ (171 to $225 \mathrm{~mm}$ ) and $219 \pm$ $44 \mathrm{~g}$ (146 to $303 \mathrm{~g})$, respectively. Two large lower beaks (9.9 and $10.6 \mathrm{~mm}$ LRL) of Todarodes sp. were also found as accumulated items; they belonged to squids with an estimated ML of 397 and $428 \mathrm{~mm}$ and an estimated mass of 1421 and $1759 \mathrm{~g}$, respectively.

Discussion. To our knowledge, this study is the first to report the species and locality of previously unknown marine resources using both dietary analysis and satellite tracking of top predators. Ommastrephid squids from Kerguelen waters were previ- 

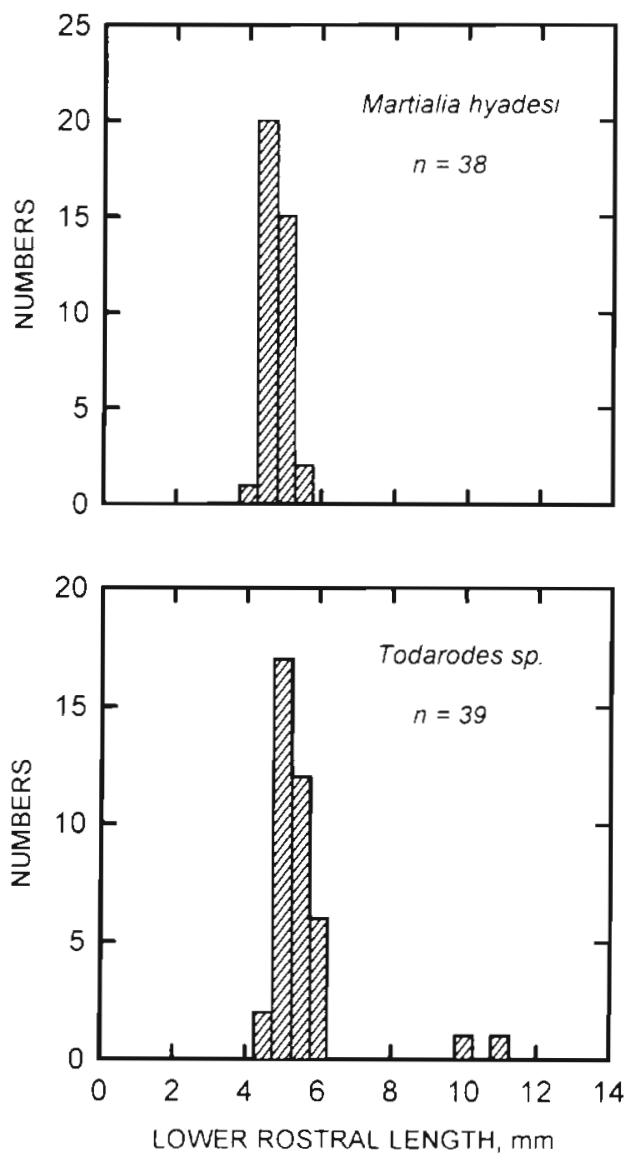

Fig. 2. Frequency distribution of lower rostral length of Martialia hyadesi and Todarodes sp. in the diet of black-browed albatrosses Diomedea melanophrys from Kerguelen Island

ously known from only a few specimens (Duhamel \& Piatkowski 1993), including only 1 individual of $M$. hyadesi (Piatkowski et al. 1991). The food and foraging trips of breeding black-browed albatrosses indicate the common occurrence of juvenile Martialia hyadesi and Todarodes sp. over the upper slope east of Kerguelen Island in February 1994. Ommastrephid squids were also a main part of the black-browed albatross' diet in other years (authors' unpubl data), thus confirming their importance for the nutrition of this top-predator species and strongly suggesting that they are a predictable marine resource in Kerguelen waters.

In agreement with a previous study using dyed birds (Weimerskirch et al. 1988), satellite tracking shows that breeding black-browed albatrosses from the colony of Canyon des Sourcils Noirs travel and forage on the shelf, shelf break and adjacent banks east of $68^{\circ} 30^{\prime}$ E during the rearing period. The concentration of birds in the 3 main feeding zones is not related to the presence of fishing vessels, as none was operating in these areas in February 1994. In the present study, the analysis of individual trips furthermore indicates that birds spent much of their time foraging over the inner shelf break area and New Bank, where the water depth was in the range of 200 to $1000 \mathrm{~m}$. They then returned in an almost straight line from these areas to the colony in a few hours to deliver the partially digested food to their chicks. The fact that a large number of crowns and mantles of ommastrephid squids were found in the chicks' stomach contents suggests that the squids were caught recently by the adults and were concentrated on the Kerguelen shelf break and New Bank. This hypothesis is supported by satellite fixes from 3 trips of individual birds that fed their chicks with ommastrephid squids (Fig. 2). Such a localisation of Martialia hyadesi and Todarodes sp. on the shelf break agrees with the known habitat characteristics of these species. Off the Namibian and South African coast, T. angolensis is mainly found on the upper continental slope (Laptikhovskiy 1989, Roeleveld 1989, Villanueva \& Sanchez 1989). In the South Atlantic, $M$. hyadesi was caught both on the upper slope of the Patagonian shelf and near the Antarctic Polar Front (Rodhouse 1991), this front lying close to the Kerguelen archipelago (Park et al. 1993)

The foraging behaviour of black-browed albatrosses in Kerguelen waters emphasizes the importance of slope areas for the nutrition of albatrosses. Satellite tracking of wandering albatrosses from Crozet Island indicates that, when performing trips of short duration, this species feeds on the shelf break (Weimerskirch et al. 1993, Weimerskirch et al. 1994). Observations at sea confirm that trend. For example, numerous albatrosses of different species forage over the continental slope off southeastern Australia outside the breeding season (Wood 1992).

The outer shelf and inner shelf break north and east of Kerguelen Island are known as productive zones subject to the influence of a NE meander of the Antarctic Polar Front (Plancke 1977, Park et al. 1993). This peculiar hydrological feature induces high phytoplankton production and, consequently, large aggregations of zooplankton and fish, including myctophid fish (see review in Duhamel 1993), which form the bulk of the food of Martialia hyadesi in the South Atlantic (Rodhouse et al. 1992). Along with the visual observation of fur seals at sea (Ensor \& Shaughnessy 1990), the foraging behaviour of black-browed albatrosses over New Bank suggests that aggregations of marine organisms also occur there. The study of the food and feeding ecology of top predators appears therefore a successful and relatively cheap way to collect useful information on marine ecosystems and food webs from remote areas, thus allowing the identification of productive zones 
Our data confirm the circumpolar distribution of Martialia hyadesi in the vicinity of the Antarctic Polar Frontal Zone (Piatkowski et al. 1991, Rodhouse 1991) All specimens of $M$. hyadesi eaten by black-browed albatrosses from Kerguelen belonged to the same size class and were juveniles, as indicated by the wings of the lower beak that were undarkened or just beginning to darken. In South Georgia, both black-browed and grey-headed albatrosses prey massively upon young, immature M. hyadesi (Rodhouse et al. 1990 , Rodhouse \& Prince 1993), and annual consumption of M. hyadesi by known predators in the Scotia Sea has been estimated to be 330000 t (Rodhouse et al. 1993). The present study is the first to find substantial numbers of that ommastrephid squid in the diet of a cephalopod feeder away from the South Georgia region, suggesting that $M$. hyadesi may also be an important prey species for top predators in other poorly known areas located in the Subantarctic-Antarctic zone.

Similar to the case for Martialia hyadesi, all but 3 individuals of Todarodes sp. eaten by black-browed albatrosses were juveniles, the wings of lower beaks being undarkened. The 3 remaining individuals were adult squids of large size with wings of the lower beak fully keratinized. Eight well preserved ommastrephid squids were collected in Kerguelen waters in February 1994 either as bycatches in bottom trawls or in stomach contents of Patagonian toothfish. There was 1 specimen of $M$. hyadesi and 7 individuals of Todarodes angolensis, a species previously unknown from that area (authors' unpubl. data). Interestingly, the specimen of $M$. hyadesi (LRL $4.1 \mathrm{~mm}$ ) belonged to the same size class as that eaten by the black-browed albatross, and the $7 T$. angolensis were either juvenile (LRL: $5.1 \pm$ $0.4 \mathrm{~mm}, \mathrm{n}=5$ ) or adult squids (LRL: 11.0 and $11.6 \mathrm{~mm}$ ), like those found in the albatross diet. These results obtained from both predators and hauls at the same time of the year suggest that only 1 size class of $M$. hyadesi and 2 of Todarodes sp. occurred in Kerguelen waters in February 1994. They also suggest that $T$. angolensis, and not the closely related species $T$. filippovae that was also found in the area (Duhamel \& Piatkowski 1993), was the species of Todarodes eaten by albatrosses.

Most ommastrephid mantles showed marks of several wounds made by the bird's beak, suggesting that the juvenile squids were probably caught alive or moribund, but not dead. Because black-browed albatrosses sample only the top $5 \mathrm{~m}$ of seawater (Prince et al. 1994), juveniles of Martialia hyadesi and Todarodes sp. must commonly occur in the epipelagic waters surrounding Kerguelen Island. Research cruises aboard fishing vessels in other areas confirm the presence of young $M$. hyadesi (Rodhouse 1991) and $T$ angolensis
(Laptikhovskiy 1989, Villanueva \& Sanchez 1989) near the surface at night performing daily vertical migration. Using stomach temperature sensors, it has recently been shown that wandering albatrosses mainly feed during daylight hours (Weimerskirch \& Wilson 1992), and preliminary data indicate that blackbrowed albatrosses from South Georgia are able to feed both at night and during the day (Croxall \& Prince 1994). The use of such devices on Kerguelen birds appears to be a promising way to ascertain if blackbrowed albatrosses catch squids through vertical migration, i.e. at night and at dawn/dusk, or whether some cephalopods are available in surface waters even during the day.

Acknowledgements. We thank Pascal Robidou for collecting squids on the French trawler 'Kerguelen de Trémarec', Paul Rodhouse for confirming the identification of Todarodes angolensis and for his comments on the text, and Dominique Beauvais and Thierry Mougey for their help in the field. This scientific work was supported financially and logistically by the Institut Français pour la Recherche et la Technologie Polaires/Terres Australes et Antarctiques Françaises, and by a grant from the Groupement de Recherche en Environnement 1069 'Ecosystèmes Polaires \& Anthropisation' (directed by Pierre Jouventin) from the Centre National de la Recherche Scientifique.

\section{LITERATURE CITED}

Clarke MR (1977) Beaks, nets and numbers. Symp Zool Soc Lond 38:89-126

Clarke MR (1980) Cephalopoda in the diet of sperm whales of the Southern Hemisphere and their bearing on sperm whale biology. 'Discovery' Rep 37:1-324

Clarke MR (1983) Cephalopod biomass - estimation from predation. Mem nat Mus Vict 44:95-107

Clarke MR (1986) A handbook for the identification of cephalopod beaks. Clarendon Press, Oxford

Croxall JP, Prince PA (1994) Dead or alive, night or day: how do albatrosses catch squid? Antarct Sci 6:155-162

Duhamel G (1993) Campagnes SKALP 1987 et 1988 aux lles Kerguelen à bord des navires 'Skif' et 'Kalper'. Les Rapports des Campagnes à la Mer N 93-01 Institut Français pour la Recherche et la Technologie Polaires, Brest

Duhamel G, Piatkowski U (1993) Calmars capturés au chalut autour des Iles Kerguelen et remarques sur leur abondance et leur rôle. In: Duhamel G (ed) Campagnes SKALP 1987 et 1988 aux lles Kerguelen à bord des navires 'Skif' et 'Kalper' Les Rapports des Campagnes à la Mer N 9301 Institut Français pour la Recherche et la Technologie Polaires, Brest, p 299-305

Ensor PH, Shaughnessy PD (1990) Fur seals over the Kerguelen plateau and elsewhere in the Southern Ocean. Polar Biol 10:481-483

Hecht $T$, Hecht A (1987) A guide to the otoliths of Southern Ocean fishes. S Afr J antarct Res 17:1-87

Imber MJ, Berruti A. (1981) Procellariiform seabirds as squid predators. In: Cooper J (ed) Proceedings of the symposium on birds of the sea and shore, 1979. African Seabırd Group, Cape Town, p 43-61 
Jouventin P, Weimerskirch H (1990) Satellite tracking of wandering albatrosses. Nature 343:746-748

Kock KH (1987) Marine consumers: fish and squid. Environm int $13: 37-45$

Laptikhovskiy VV (1989) Diel vertical migrations of the arrow-squid Todarodes angolensis Adam (Cephalopoda, Ommastrephidae) in Namibia waters. Oceanology 29: $630-631$

Lu CC, Williams R (1994) Kondakova longimana Filippova, 1972 (Cephalopoda: Onychoteuthidae) from the Indian Ocean sector of the Southern Ocean. Antarct Sci $6: 231-234$

Montevecchi WA (1993) Birds as indicators of change in marine prey stocks. In: Furness RW, Greenwood JJD (eds) Birds as monitors of environmental change. Chapman \& Hall, London, p 217-266

Park YH, Gambéroni L, Charriaud E (1993) Frontal stucture, water masses, and circulation in the Crozet basin. $\mathrm{J}$ geophys Res 98:12361-12385

Plancke $J$ (1977) Phytoplankton biomass and productivity in the subtropical convergence area and shelves of the Western Indian Subantarctic islands. In: Llano GA (ed) Adaptations within Antarctic ecosystems. Smithsonian Institution, Washington, p 51-73

Platkowski U, Rodhouse PG, Duhamel G (1991.) Occurrence of the cephalopod Martialia hyadesi (Teuthoidea: Ommastrephidae) at the Kerguelen Islands in the Indian Ocean sector of the Southern Ocean. Polar Biol 11:273-275

Prince PA, Hum N, Weimerskirch H (1994) Diving depths of albatrosses. Antarct Sci 6:353-354

Rodhouse PG (1990) Cephalopod fauna of the Scotia Sea at South Georgia: potential for commercial exploitation and possible consequences. In: Kerry KR, Hempel G (eds) Antarctic ecosystems. Ecological change and conservation. Springer-Verjag, Berlin, p 289-298

Rodhouse PG (1991) Population structure of Martialia hyadesi (Cephalopoda: Ommastrephidae) at the Antarctic polar front and the Patagonian shelf, south A.tlantic. Bull mar Sci 49:404-418

Rodhouse PG, Croxall JP, Prince PA (1993) Towards an assessment of the stock of the ommastrephid squid Martialla hyadesi in the Scotia sea: data from predators. In: Okutani $T$, O'Dor RK, Kubodera $T$ (eds) Recent advances in fisheries biology. Tokai University Press, Tokyo, p 433-440

This note was submitted to the editor
Rodhouse PG, Prince PA (1993) Cephalopod prey of the black-browed albatross Diomedea melanophrys at South Georgra. Polar Biol 13:373-376

Rodhouse PG, Prince PA, Clarke MR, Murray AWA (1990) Cephalopod prey of the grey-headed albatross Diomedea chrysostoma. Mar Biol 104:353-362

Rodhouse PG, White MG, Jones MRR (1992) Trophic relations of the cephalopod Martialia hyadesj (Teuthoidea: Ommastrephidae) at the Antarctic polar front, Scotia Sea. Mar Biol $1.14415-421$

Rodhouse PG, Yeatman J (1990) Redescription of Martialia hyadesi Rochebrunne and Mabille, 1889 (Mollusca: Cephalopoda) from the Southern Ocean. Bull Br Mus nat Hist (T: Zool) 56:135-143

Roeleveld $1 A$ (1989) The occurrence of two species of squid Todarodes in the Benguela system. S Afr J Sci 85: $659-663$

Villanueva R, Sanchez, P (1989) Some data on the biology of the squid Todarodes angolensis (Cephalopoda: Ommastrephidae) in Namibian waters. Int Comm Southeast Atl Fish Sel Pap 1:17-22

Weimerskirch H, Bartle JA, Jouventin P, Stahl JC (1988) Foraging ranges and partitioning of feeding zones in three species of southern albatrosses. Condor 90:214-219

Weimerskirch H, Doncaster CP, Cuenot-Chaillet F (1994) Pelagic seabirds and the marine environment: foraging patterns of wandering albatrosses in relation to prey availability and distribution. Proc R Soc Lond Ser B 255: 91-97

Weimerskirch $H$, Robertson G (1994) Satellite tracking of light-mantled sooty albatrosses. Polar Biol 14:123-126

Weimerskirch $H$, Salamolard $M$, Sarrazin F, Jouventin $P$ (1993) Foraging strategy of wandering albatrosses through the breeding season: a study using satellite telemetry. Auk 110:325-342

Weimerskirch H. Wilson RP (1992) When do wandering albatrosses Diomedea exulans forage? Mar Ecol Prog Ser 86:297-300

Williams R, McEldowney A (1990) A guide to the fish otoliths from waters off the Australian Antarctic territory. Heard and Macquarie Islands. ANARE Research Notes 75. Hobart

Wood KA (1992) Seasonal abundance and spatial distribution of albatrosses off central New South Wales. Aust Bird Watcher 14:207-225

Manuscript first received: April 24, 1995

Revised version accepted: July 3,1995 